\title{
Showing 'heart' while making money: negotiating proximity in a Ugandan marketplace
}

\author{
William Monteith
}

\begin{abstract}
Introduction
Markets are important for building society ... People come from all over the country and learn to lose their bad habits and to be in one line; to have a good heart [omutima] and to help others. (Edward Walusimbi, airtime vendor)
\end{abstract}

These days, people in the market are many, and their hearts are not good. (Jane Nalumu, tomato vendor)

African marketplaces have long been understood as ambivalent spaces; as sites of compliance and transgression; domination and resistance (Bohannan and Dalton 1962; Clark 1994; Kapchan 1996; Pietilä 2007). This ambivalence comes into sharp focus in the urban markets that have absorbed a large proportion of the African workforce over the past four decades. ${ }^{1}$ One the one hand, urban markets offer opportunities for the forging of new relationships, or 'fictive kin', beyond of the confines of consanguinity and affinity. However, on the other, they are intensely competitive places in which strangers 'skilfully intrude into one's life' (De Boeck and Plissart 2004: 189). Succeeding in the market therefore requires the striking of a skilful balance between accumulation and redistribution, disclosure and concealment.

This article explores the ways in which people navigate socio-economic relationships in Nakasero market, the oldest marketplace in Kampala, Uganda. While much of the ethnographic scholarship on African cities focuses on the social and moral worlds of discrete constituents, such as the young male 'hustler' (Frankland 2007; Jones 2010; Weiss 2002) and female market vendor (Clark 1994; Kapchan 1996; Musisi 1995), I examine the day-to-day interactions that take place between people of diverse socio-economic backgrounds, facilitated by the work of Alex Sserwanda, a waste picker in the market. ${ }^{2}$ As Alex makes his rounds in Nakasero, he engages in a number of channels through which information, goods and labour are exchanged. I show that these channels are shaped by the dual imperatives of individual accumulation and interpersonal obligation,

\footnotetext{
William Monteith is a lecturer in the School of Geography at Queen Mary University of London. He researches questions of work and sociality at the margins of urban economies. Since 2016, he has led a project on the participation of urban displaced populations in markets in Kampala, Uganda. Email: w.monteith@qmul.ac.uk

${ }^{1}$ The informal sector in Uganda is growing at an annual rate of 20 per cent in urban areas, a process that can be traced back to the economic reforms and structural adjustment programmes of the late 1970s (Singer et al. 2015: 35).

${ }^{2}$ The particular day covered is Sunday 15 June 2014, although the majority of the interactions described here take place on a daily basis. All names have been anonymized.
} 
invoked through moral notions of 'heart' (omutima), which have a long history in Buganda.

The following section provides an overview of the evolution of structural and post-structural approaches to social relationships in urban Africa. I then provide an outline of cultural frameworks of kinship in Buganda, the region in which Kampala is located. The remainder of the article offers an empirical investigation of the utility of these frameworks for understanding social interactions in Nakasero market.

\section{Kinship in urban Africa: from the dysfunctional to the elusive}

Much colonial anthropology was underpinned by a dualist conception of African society in which the 'modern' town was detached from the 'traditional' countryside. Towns such as Kampala were characterized as dysfunctional insofar as they failed to integrate different groups into social and cultural systems recognized by the researcher. For example, Southall and Gutkind (1957: 210) bemoaned the 'lack of any widely agreed scale of values for the systematic ordering of relationships between persons of different ethnic origin, of different skin colour, different wealth or different occupation'. Such concerns underpinned colonial attempts to segregate the 'traditional' way of life of the tribe (kisendji), from the 'civilized' way of life of the towns (kizungu), where each was seen to pose the threat of contamination to the other (Epstein 1967: 279). It also perpetuated a long-standing association between the city and the 'alien' and 'immoral' in Africa (Teppo 2015: 284), which continues to demarcate the urban market as a particularly transgressive place (De Boeck and Plissart 2004: 189).

This dualist genre has its origins in the Chicago School, in which Robert Park and students such as Louis Wirth (1938) approached the modern city as a site of the breakdown of community ties, taking inspiration from European theorists such as Durkheim and Simmel. The genre proved remarkably resilient in Africa in the decades following colonial rule, despite the attempts of a number of scholars - predominantly associated with the Rhodes-Livingstone Institute to document the connections between urban and rural life (Gluckman 1971; Mayer 1971). However, this has since given way to what has been termed a 'realist' (Guyer 2011) or 'post-normative' turn (Brennan 2013), following a sustained critique of structural approaches in the 1990s. At the genesis of this scholarship, Mbembe and Roitman (1995: 326) advocate a theorization of the African city not as a preconceived system but as a 'routinization of a register of improvisations lived as such by people', shifting the emphasis from the domain of 'crisis' to the 'banal' and everyday (ibid.: 326).

Scholars have responded by suppressing structural concerns in order to explore the 'invisible city' (De Boeck and Plissart 2004), the 'elusive city' (Nuttall and Mbembe 2008), and 'the city yet to come' (Simone 2004a). Summarizing these contributions, Jane Guyer observes an emerging methodological imperative to 'walk the city' rather than gather subjective accounts of it, documenting symbols, expressions, opportunities and constraints as they present themselves: things that 'burst out of the conventional forms and [have] not yet taken a newly conventionalized shape' (Guyer 2011: 475). Established social science concepts such as culture, ethnicity, gender and class are relegated in the search for 
'new forms of sociality and new topographies of propinquity' that emerge where material infrastructures break down (De Boeck and Plissart 2004: 231).

In his seminal work on Johannesburg, AbdouMaliq Simone describes the city as 'a conjunction of heterogeneous activities' which constitute 'highly mobile and provisional possibilities for how people live and make things, how they use the urban environment and collaborate with one another' (Simone 2004b: 410). Regularities thus ensue 'from a process of incessant convertibility - turning commodities, found objects, resources, and bodies into uses previously unimaginable or constrained' (ibid.: 410). Simone terms this process 'people as infrastructure', drawing attention to the role of social relationships - rather than material infrastructures - in generating stability and regularity in the city (ibid.: 411).

This period of epistemological renewal is overdue. Nevertheless, by foregrounding the novel and provisional interactions encountered while walking the city, there is a tendency in sections of the realist literature to downplay the historical and cultural continuities against which these interactions are understood. Furthermore, its suppression of subjective accounts represents a diversion from the conventional ethnographic goal of prioritizing the categories and concepts of the (urban) respondent. In Nakasero market, people's frequent invocations of notions of 'heart' (omutima) and obligation were suggestive of the need to take seriously the historical cultural spaces in which social relationships are situated. In the case of Kampala, this necessitated an engagement with the Buganda kingdom.

\section{Cultural frameworks of urban kinship: Kiganda idioms in Kampala}

'Heart' and 'love' are recurrent idioms in the literature on social relations in Buganda, ${ }^{3}$ which takes its theoretical cue from anthropological discussions of the concept of 'wealth in people' (Gluckman 1956; Guyer 1993). Within this literature, two contributions are of particular value for understanding expressions of kinship in Nakasero market.

First, Holly Hanson (2003) writes that the social and political organization of precolonial Buganda was based around the intricate relationship between love and power. Power was not a zero-sum game in which people had it only for as long as others did not; instead, it was something that had to be assembled, which people had only for as long as others agreed that they had it (ibid.: 17). The Baganda used ties of reciprocal obligation 'to create connections, to incorporate strangers, and to vanquish competitors' (ibid.: 3). Leaders were obliged to give gifts of food and land to their followers, and accountability was provided by the ease with which followers could switch allegiance from one leader to another. This system produced a logic in which 'those who wielded power had to appear loving in order to hold onto their followers' (ibid.: 17). Hanson argues that, as a result, the Baganda had a historical advantage over foreign employers in attracting and retaining labour.

\footnotetext{
${ }^{3}$ Buganda is the name of the region, Baganda the people and Kiganda the culture (often shortened to 'Ganda').
} 
Second, China Scherz (2014) provides an account of social relations in contemporary Buganda through ethnographic case studies of a rural church and international NGO. She argues that strategies of self-making in Buganda involve creating and using networks (which are often hierarchal) to secure support (which is often material)' (ibid.: 2). Relationships are regulated by cultural logics of patronage and moral notions of having 'a heart for helping' others (omutima omuyambi). Scherz argues that international NGOs are seen to violate these frameworks through their refusal to give 'handouts' (ibid.: 142). Consequently, dependence and inequality are not considered social evils in and of themselves in Buganda; rather, it is a breakdown in the practice of helping others that is a source of moral anxiety (ibid.: 96).

The marketplace offers an interesting site in which to explore the salience of cultural registers of kinship in the city due to both its heterogeneity (67 per cent of people in Nakasero self-identify as Baganda) ${ }^{4}$ and the presence of forms of market exchange that appear to be in conflict with notions of patronage and redistribution. This tension is reflected in the contrast between discussions of "wealth in people' in the anthropological literature (Gluckman 1956; Guyer 1993) and 'forced solidarity' in the micro-entrepreneurship literature on urban Africa (Baland et al. 2011; Grimm et al. 2013). Seeking out a path between these debates, Erik Bähre (2007: 33) reminds us that 'ambivalence is crucial to an appropriate analysis of solidarity' - and, by extension, kinship - in urban African settings.

This article makes an empirical contribution to this debate based on twelve months of ethnographic fieldwork in Nakasero market, Kampala. ${ }^{5}$ Nakasero was an archetypal British colonial market whose access was tightly controlled; it was restricted first to Kampala's European and Asian populations, and then to traders who followed the construction of the railway west from Kenya. ${ }^{6}$ Today, the physical infrastructure of the market appears much as the British administration planned it in 1927. However, its population has expanded from a few hundred Asian spice vendors to over 10,000 people from across Uganda and the broader region, making a living as vendors, traders, hawkers, transporters, cleaners and various other service providers. As Edward notes in the epigraph cited at the beginning of this article: 'People come from all over the country and learn to lose their bad habits and to be in one line.'

The remainder of this article explores the ways in which people negotiate social and economic obligations in Nakasero - showing heart while making money - by tracing the daily interactions of five different people in the market.

\section{Negotiating proximity in Nakasero market}

\section{Dawn: waking up on Market Street}

Alex Sserwanda wakes up in Nakasero market on cardboard packaging emblazoned with the logos of 'Tru-Cape Pears' and 'Gadco Oranges'. He is woken

\footnotetext{
${ }^{4}$ Based on a survey of 229 people in 2014 (response rate of 97 per cent).

${ }^{5}$ See Monteith (2017a) for a discussion of the ethical and methodological issues encountered during fieldwork, and their implications for the practice of urban ethnography more broadly.

${ }^{6}$ See Monteith (2017b) for an extended history of markets in Kampala, and their contribution to a form of indigenous urbanism.
} 
by Frank Motovu, who arrives to open a hardware shop at around 6 a.m. It is already light and the road is alive with activity as vendors arrive to set out their produce on makeshift cloths and wooden stalls. Wearing a stained linen shirt, torn brown trousers and plastic flip-flops, Alex gets up to acknowledge Frank's arrival before crossing the road to the 'Ghetto' where a group of men rest among wooden crates and wheelbarrows adjacent to the market rubbish dump (see Figure 1).

Different areas of the market take their names from the populations and activities that characterize them. The 'Ghetto' is a reference to the struggle through which men in the area make a living. ${ }^{7}$ Like 'Jamaica' in Nakasero and 'Benghazi' in nearby Kisekka market, 'Ghetto' invokes a certain style that renders the space more accessible to young men. It is the only area of Nakasero where smoking (tobacco and marijuana) and drinking (cane spirit) take place. The sweet, putrid scent of rotting fruit builds as the rubbish dump grows over the course of the day. Like most of the men here, Alex makes a living transporting waste to the dump from different areas of the market, drinking between shifts to dull the smell of the debris. ${ }^{8}$ His job is a common entry point for men arriving in Kampala without significant social or economic capital, offering their 'bare lives' to the market (Simone 2004b: 428). Their work involves engagement in demanding forms of physical labour - such as heavy lifting - associated with long-term health conditions (Owusu-Sekyere 2014).

Alex arrived in Nakasero in 2012. Orphaned at a young age, he was brought up by his grandparents in Rukungiri, western Uganda, dropping out of primary school to help them cultivate a small piece of land. Alex left the village for Kampala at the age of twenty in search of an income. He visited Nakasero because it was known to be a 'very rich market' that provided possibilities for 'newcomers' (bapya), and survived initially on food discarded by fruit and vegetable vendors. He describes being beaten and evicted by other men working in the Ghetto during this period - a common experience for young men entering the market without prior contacts or capital.

After a few weeks, Alex met a female stall vendor who offered to pay him 500 Ugandan shillings (USh) (US\$0.13) to carry discarded produce to the dump every day. Seeing that he could do the job 'well' and for a 'cheap' price, her neighbours also started to give him work and he built up a regular base of six clients. $\mathrm{He}$ spent some of his first earnings on tobacco, which he shared with 'big men' in the Ghetto - literally, men of big physical stature - in order to guarantee his safety in the market. Summarizing his relationship with Nakasero, he says he 'loves' it 'very much' because it 'feeds' him (kekandiisa) and has enabled him to purchase livestock in his village in Rukungiri.

Alex's residence in the market exposes him to aspects of the Ugandan legal system largely avoided by stall vendors. Since 2012, he has been arrested on multiple occasions for offences under the colonial Vagrancy Act, used to remove people marked 'unproductive' from the city centre after dark. After their arrest,

\footnotetext{
${ }^{7}$ The English term 'struggle' is embossed on the handles of wooden wheelbarrows in the market.

${ }^{8}$ According to UN-Habitat (2010), waste pickers without written contracts - such as Alex perform more than half of all waste collection activities in the global South.
} 


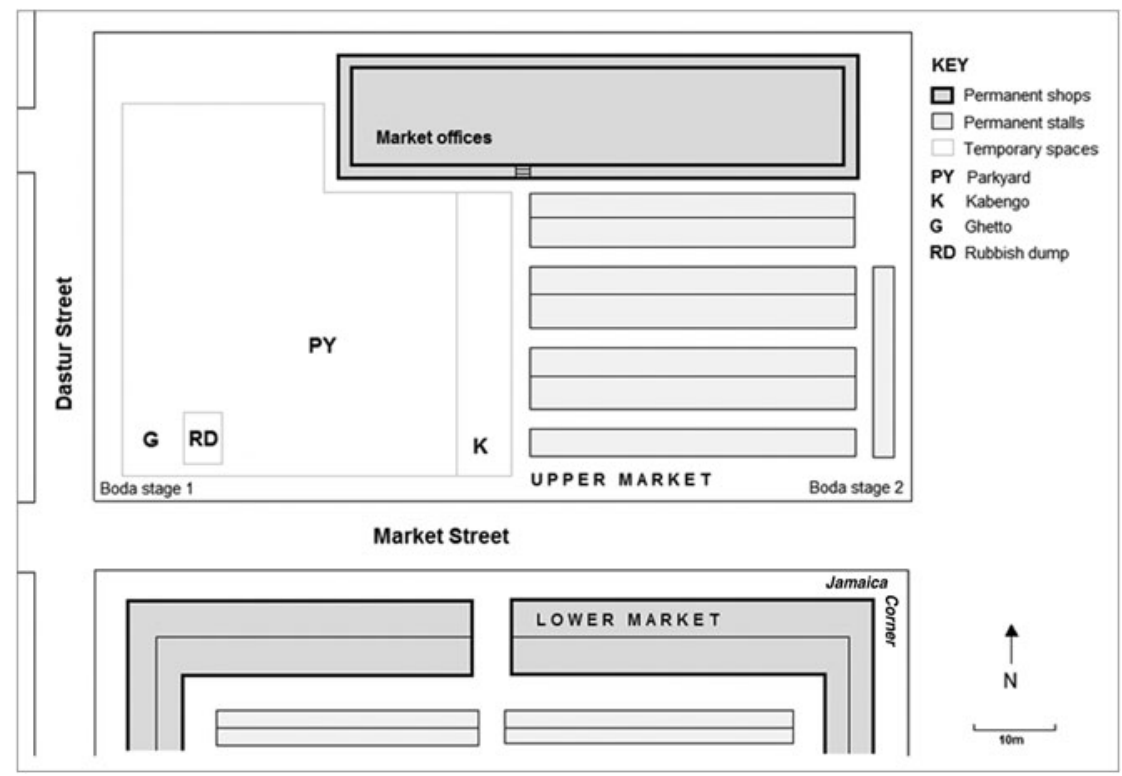

FIGURE 1 Map of upper Nakasero market, central Kampala.

detainees in Kampala are taken to prison farm facilities where they are retained on recurrent cycles of remand until a guarantor offers to post bail. ${ }^{9}$ Alex's most recent arrest ended at Nakasero police post, when one of his employers secured his release with a loaned payment of USh 15,000 (US\$5.20). As a self-declared 'low-income' worker in the market, Alex has not been able to rent a room in Kampala. However, he notes that Frank's shop offers him a place of relative safety at night.

Sitting in front of his laptop in his shop across the street, Frank describes his feelings on finding Alex and others in the doorway each morning: 'I feel sorry because I know they are poor people ... they give my shop security at night and I know they are not thieves.' Raised in Kampala, Frank began working for one of his mother's four businesses in Nakasero in 2010 while studying for a degree in microfinance. His entry into the market was eased by both his family connections and the entry barriers that protect the shops from the more intense forms of competition present in other areas of the market. However, his rapid ascent was seen to contravene local processes of advancement in Nakasero and older vendors were initially reluctant to greet him: 'They feel bad; they expect that you have to be in the market for thirty years for that.' Economic progression in

\footnotetext{
${ }^{9}$ Of Uganda's 32,000 prisoners in 2010, 19,500 (61 per cent) were on remand, where most will remain for a number of years. The official capacity of Uganda's prisons is just 13,000 (see 'Uganda: remand prisoners incarcerated for years', Institute for War and Peace Reporting, 21 September $2010<$ <ttp://www.ecoi.net/local_link/146455/247362_en.html>, accessed 10 September 2017).
} 
the market is a process that is understood to require an investment in the lives of others.

After opening the store, Frank fields calls from customers and suppliers, including his mother, who frequently travels to China and Dubai in search of new exporters. He wears a light-coloured linen shirt, black trousers and shiny black shoes the uniform of a 'serious' (siriyaasi) businessman in Nakasero. Sales here take place at a more relaxed pace than in other areas of the market as goods are non-perishable and profits do not require large numbers of transactions.

Recalling his early memories of the market, Frank describes taking part in an overnight protest in 2008. He attended the event with his mother and two sisters following the leaking of a city council report revealing plans to sell off the market: 'When you see mabati [iron sheets] in Kampala, it means something has been taken.' 10 Recalling the excitement of the evening, he concedes that it wasn't until he 'grew up' that he understood why his mother had taken him. The protest was an important act in 'defence' of Nakasero, a place that has since become fundamental to his life: 'Everything I eat, I drink, I use, it comes from Nakasero market.'

When describing other people in Nakasero, Frank differentiates between 'high' and 'low' earners - a common distinction in the market. While the former are understood to be well educated and to sell 'many items', the latter are seen as largely uneducated ('without maths and English'), and capable only of 'small' business on the fringes of the market. These two categories of person are also invoked through the binaries of big/small (nene/tono) and known/unknown (amandyikidwa / atamandyikidwa). Different categories of person are associated with different categories of goods and spaces. For example, while high earners are seen as selling 'first-class' produce from covered shops and stalls, low earners are understood to sell 'third-class' produce in the open areas of the market. As one stall vendor explained: 'We sell things which are first class; if I get lower-class things I can give them to [Alex].' For his part, Frank stresses the importance of supporting low earners by offering them work and advice, on the understanding that 'the market is supposed to be for poor people'.

On first inspection, Alex and Frank's interaction represents a simple exchange that is of practical benefit to both men: Alex enjoys the relative shelter of a shop veranda at night while Frank receives security for his shop. However, both men understand this interaction with reference to ideas that transcend individual self-interest. First, they invoke an idea of the market as a common resource or institution capable of providing for all those who live and work there. Second, they note that the proper functioning of the market is underpinned by an ethic of reciprocal obligation, which compels high earners such as Frank to offer work and advice to 'low earners' such as Alex, having 'a heart for helping', that is.

\section{Morning: cleaning in the upper stalls}

Alex leaves the Ghetto at around 9 a.m. and walks through the Parkyard and Kabengo to the oldest area of the market, the upper stalls. This area of the market is home to many of the relatives of the first Kenyan Jaluo traders in

\footnotetext{
${ }^{10}$ See 'Vendors strike over leaked report', Daily Monitor, 26 February 2008.
} 
Nakasero. Women sit in pairs in front of colourful displays of fruit and vegetables apples, oranges, grapes, pears - originating from as far as Egypt and South Africa. The stalls are decorated with newspaper clippings featuring pictures of Monsignor Aloysious Ngobya, Kabaka Ronald Muwenda Mutebi II, and Wayne Rooney. ${ }^{11}$

The majority of customers in the upper stalls originate from outside Uganda. Chinese, Sudanese and first- and second-generation Indian customers purchase produce in kilogrammes, rather than the 'heaps' preferred in the open areas of the market. Higher rents mean that this is generally the most expensive area of the market to purchase goods. Interactions are regulated by a number of common principles. For example, immediate neighbours are prohibited from selling the same goods as each other, creating a four-category rotation between domestic fruit, domestic vegetables, imported fruit and imported vegetables. Different categories of goods are associated with different categories of customer, leading vendors to state 'I am selling for the Indians' or 'These things are for the Chinese.'

There is an understanding that the customer is the active agent (or 'king') in the market. Once a customer has shown interest in another vendor's goods, even if only by standing in front of their stall, no other vendor is permitted to address them until they have broken off negotiations by physically leaving the space in front of the stall. To do otherwise is to violate 'the firmest and most universal convention' of the market (Clark 1994: 129), and likely to lead to an accusation of stealing other people's customers. ${ }^{12}$ These understandings serve to preserve the bargaining position of vendors while reducing the possibility of conflict. Nevertheless, they are frequently contested, and vendors rarely leave their stalls for fear of losing their regular customers.

Vendors call out to Alex as he makes his way down the aisle between the first rows of stalls: 'Alex jangu' ('Alex come'), 'Kasasilo jangu' ('Rubbish come'). His first job is for Margaret Abuya, a young Kenyan woman who runs a family produce business at the end of the row. Alex greets Margaret and begins sweeping the debris behind her stall into two piles, separating waste for the dump from salvageable 'second-class' or 'third-class' produce that can be sold in the Ghetto.

Customers are also called with the 'tongue' (olulimi). Female vendors use gentle but persuasive language to invoke fictive kin relations, such as 'brother', 'sister', 'mama', 'boss' and 'master'. They also mobilize household obligations through prompts such as 'For madam!' or 'For the kids!' One elder female vendor likened her customers to women from whom she feared becoming 'divorced' or 'separated' (okwawukana) as a result of their contact with hawkers on the outskirts of the market. Idioms of kinship and marriage arguably reflect an attempt on behalf of the vendors to 'domesticate' the marketplace and render it readable (and profitable) through appeals to the personal (Pietilä 2007: 32). However, this process also engenders feelings of envy and jealousy, for example on the occasion of a customer's perceived elopement.

\footnotetext{
${ }^{11}$ The leader of the Faith of Unity and Oneness, the King of Buganda, and the English Premier League footballer, respectively.

${ }^{12}$ Researching Kampala's night markets, Musisi (1995: 133) observes the use of disguised language in the regulation of such situations, including metaphors such as 'step not in my throat' (do not take my customer).
} 
Women generally enter the market as apprentices or employees for female extended family members. Rather than threats of physical violence experienced by Alex, women often face accusations of moral transgression. For example, a young Mugisu woman was constantly accused by her female neighbours of being a 'husband snatcher' during her first months in the market as a result of her interactions with male customers. Female vendors were also frequently accused of witchcraft, particularly during periods of business success. The practice of witchcraft is thought to involve the placing of charms - such as sticks and stones wrapped in barkcloth - under the stalls of competitors. A male vendor who left the market after his wife became ill complained that she had been bewitched on account of the fact that they were making 'a lot of money'.

Labels such as those of the 'husband snatcher' and the 'witch' (omulogo) invoke a moral transgression that rationalizes the social isolation of the accused, rendering them 'nonrelational persons' (Englund 1995). Accusations of witcheraft in Nakasero serve to place limits on individual accumulation, functioning as what Geschiere (1997) terms the 'shadow side' of kinship - or the stick enforcing the redistributive ethic of omutima omuyambi. Nevertheless, people succeed in generating significant amounts of profit in the market. Those most at risk of isolation are newcomers (bapya), whose profits are deemed to be disproportionate to their social relationships (or followers). Economic progression is understood to require an investment in people, in addition to an investment in goods (Guyer 1993). As a consequence, younger vendors give money conspicuously, through donations to burials and church collections, and accumulate it discreetly, for example by investing in livestock in their ancestral village.

Margaret recalled being 'teased' during her initial period in the market. However, like Frank, her entry was eased by her family's historical connections in Nakasero. She mastered Luganda quickly, with the help of her friends and family, and her mother gave her an adopted Ganda name (Namuddu) after the nurse who delivered her. Reflecting on what Nakasero means to her, Margaret says she feels 'proud' to work in the same place as her parents, and that her neighbours often ask after them. Her profits qualify her as a high earner, based on Frank's dichotomy. In addition to a base of regular market customers, she also supplies produce to a chain of restaurants in Kampala and to safari lodges in two of Uganda's national parks. Fulfilling these orders requires access to transport (a company vehicle) and flexible credit facilities from suppliers, resources that only established stallholders are able to draw upon.

Like Alex and Frank, Margaret's formative experiences in the market also included confrontations with state security services. In 2012, she was exposed to police tear gas on a day in which opposition leaders visited the market. ${ }^{13}$ Police operations have become so commonplace in Nakasero that vendors have developed systemized responses to tear gas exposure, including the distribution of water and towels, and the recruitment of groups of men to transport injured persons to sheltered areas of the lower market. After her own experience, Margaret vowed never to work in Nakasero again, but later reconsidered following the reassurances of her family.

\footnotetext{
${ }^{13}$ 'Police teargas opposition leaders', NTV, 21 May $2012<$ https://www.youtube.com/watch? $\mathrm{v}=\mathrm{V} 3$ MoseWcFmU>, accessed 20 April 2015.
} 
Discussing Alex's work in the market, Margaret says that she employs him because he is 'cheap' and 'dependable'. She adds that the work is 'hard' and 'these people, they are trying to survive', drawing upon similar notions of livelihood and support to those invoked by Frank. In addition to a daily payment of between USh 1,000 and 2,000, Margaret also supports Alex in other unspecified ways: for example, she has previously secured his release from the local police post through payments to police officers.

Margaret also stresses the importance of the labour conducted by Alex and his colleagues in the Ghetto for maintaining the cleanliness of the market, establishing a connection between their work and a larger project in which a great many people are invested. By employing Alex, Margaret shows 'heart' by fulfilling an obligation to feed others, while avoiding forms of labour that could be damaging to her health and her reputation as a respected woman and high earner in Nakasero.

\section{Afternoon: customer calling in the Kabengo}

Alex works in the upper stalls until just before midday, transporting waste back to the dump in time for the arrival of the municipal rubbish truck. The early afternoon hours are the quietest period of the market day, animated only by the work of waitresses who carry hot, heavy plates of food from market restaurants to vendors in their shops and stalls.

On his way back to the dump, Alex passes through the Kabengo, a thin corridor that lies between the sheltered upper stalls and the open area of the market (see Figure 1). The liminal position of the Kabengo provides it with access to both the Ugandan customers shopping in the open areas of the market and the international customers heading in and out of the stalls. The name kabengo translates literally as 'pain in the stomach or spleen', and is thought to originate from the complaints of nearby stall vendors.

As he passes, Alex nods to acknowledge Stephen Kalule, a produce vendor dressed in a bright pink polo shirt, jeans and trainers selling coriander from a plastic sack on the floor. Vendors here are among the youngest in the market. However, unlike those in the Ghetto, many hold aspirations of returning to school to attain a secondary qualification. Low levels of capital and high levels of competition mean that they remain low earners relative to Frank and Margaret and their neighbours in the shops and stalls. Lacking access to permanent storage facilities, Stephen purchases sacks of produce in the morning wholesale market and sells them in loosely assembled heaps and bundles over the course of the day. Rather than monthly rent, he pays a daily fee (USh 1,000) to the city council.

The spatial organization of the Kabengo reflects the municipal politics of the day, adhering strictly to the contours of the pavement during times of council enforcement operations and spreading far out into the road during periods of inactivity (typically on Sundays and during election cycles). Stephen explains: 'KCCA [Kampala Capital City Authority] is like electricity, they come and we move, they go and we move back' - a metaphor that is enhanced by the bright yellow uniforms worn by enforcement officers.

The absence of material infrastructure in the Kabengo encourages an innovative use of space, allocated through prolonged processes of jostling and negotiation. As one of Stephen's neighbours explains: 'We make our own market.' Entry requires 
the consent of one's neighbours, established through an extended period of socialization and exchange, including the provision of favours such as watching a person's produce while they are away. New entrants begin by selling in the road on the outside edge of the Kabengo, which entails the risk of having stock confiscated by the city council. They then seek to move their goods inside by cultivating relationships with their immediate neighbours.

In the absence of a process of formal allocation, vendors demonstrate ownership of space through improvised performances of social confidence, drawing upon registers unique to this particular area of the market. Many of the young men adopt martial identities through pseudonyms such as 'Sergeant', 'Soldier Boi', 'Golola' (a renowned Ugandan boxer) and 'Ogugu family' (a fictitious kin group). These identities are invoked and defended through rehearsed performances of speech, singing and rap, reinforcing connections between people and spaces in the market.

Different customers are met with different treatment. For example, elder Ugandans are addressed in respectful terms, such as Nyabo ('Madam'), Muzee ('Elder'), 'Sister' and 'Brother', similar to those used in the upper stalls. In contrast, younger customers - particularly those of the opposite sex - are met with flirtatious calls such as 'Hey baby!', 'Big arms!' and 'Long time!' Meanwhile, East Asian customers receive calls of 'Xiansheng!', 'Huang gwa!' and 'Cong!' ('Mister', 'Cucumber' and 'Spring onion') in Mandarin, and South Asian customers of 'Bani!', 'Gajara!' and 'Bhindi!' ('Boy', ${ }^{14}$ 'Carrot' and 'Okra') in Hindi. Loose cultural references such as 'Jackie Chan!' and 'Salman Khan!' are also commonplace - anything to gain the attention of a potential customer. There is also a physical intimacy to vendor-customer interactions in this area of the market. What initially appears to be a tense confrontation - serious expressions, raised voices, physical gesturing - often reveals itself to be a spirited, pre-rehearsed negotiation.

Stephen grew up in Luwero District, 40 miles from Kampala. He left school without a secondary qualification and moved to the capital to live with an older brother. At the age of seventeen, he started working in a bookstore on a street adjacent to Nakasero, occasionally picking up produce from the market for his boss. After several months, he decided to leave the job in order to try to sell plastic bags (kaveera) in the market, fulfilling a desire to be self-employed. Stephen describes his initial months in the market as a 'struggle to get known' (amandyikidwa). Before employing someone to carry their shopping, customers ask nearby vendors of their reputation in the market; of whether they are a 'good boy' (omwana mulamu) with a 'good heart' (mutima bulamu). Stephen developed relationships with vendors in the Kabengo by bringing them customers from the street and helping them with tasks such as carrying produce to their stalls. He describes established vendors as his 'elders', who eventually granted him a small space to sell from.

A 'good boy' in the market is generally understood to be someone who uses their full family name as opposed to a pseudonym, abstains from crime, drugs and alcohol, and 'speaks well' by addressing people clearly and confidently in a

\footnotetext{
${ }^{14} \mathrm{~A}$ term originally used by Indian businessmen as an infantilizing refrain to Ugandan labourers, now reversed by vendors in Nakasero.
} 
register that is appropriate to their status. A common critique of younger vendors is that they don't know how to 'speak' (okwogera). Stan Frankland (2007: 40) writes of the expectation for Ugandan youth to be 'deferential, subservient and immune to the fashions of the West'. Accordingly, success in the open areas of the market requires young people to 'speak' in multiple registers; to master the soft, deferential tones expected by customers and suppliers as well as the loud, self-confident performances geared towards their neighbours and competitors.

If the labels of 'witch' and 'husband snatcher' are the most feared by women in the market, those of muyaye (thug, idler or defiant; plural: bayaye) or 'bad boy' threaten the reputation of young men. Writing about Nakasero market in 1990, Alja Naliwaiko asserts that bayaye are people who are 'lost' in relation to the 'moral values of their society' (1990: 61). ${ }^{15}$ Like the witch, the muyaye is a nonmarket person, for whom normal patterns of relationships and obligations may be suspended. Such labels serve important functions for potential employers and customers insofar as they provide a degree of predictability to interactions with unfamiliar persons: a key problematic of market life. However, the term is also used by vendors in the upper stalls to rationalize the denial of work to young men in the open areas. As such, success in the Kabengo requires the careful navigation of these categories, presenting oneself as a 'good boy' rather than a muyaye.

Stephen's relationship with Alex could be described as casual. The two men engage in occasional bets and debates on topics ranging from the outcome of boxing matches in Los Angeles to the time it takes to get to Fort Portal for a burial. However, Stephen and his neighbours rarely enter the Ghetto due to its association with deviant activities, such as smoking and drinking. Pooling resources, they pay for the cleaning of the Kabengo each evening by Alex and his colleagues. Explaining why he makes his contribution, Stephen says: 'As you know, everybody here depends on each other.' Unlike Frank and Margaret, he makes no mention of notions of sponsorship or support, or of the categories that differentiate him and Alex. As such, his status as a fellow low earner arguably frees him from some of the ties of obligation felt by wealthier members of the market. His relationship with Alex is one of a fictive sibling, rather than an elder.

\section{Evening: making a deposit in the House of Faith}

The market wakes from its afternoon slumber at around 4 p.m. as commuters start to filter through on their journeys back from work. Vendors in the Parkyard and Kabengo rearrange their stock, balancing shiny, unblemished fruit on top of neat piles of less desirable produce. The edges of the market bulge as customers conduct quick transactions by the roadside. Stephen calls out to customers in the Kabengo, while Alex embarks on a second round of the upper stalls, building the rubbish dump in the process. Frank and Margaret begin counting their takings in preparation for closing.

On his final round of the market, Alex passes a man with a large blue book, engaged in an animated conversation in the Parkyard. The man is wearing dark

\footnotetext{
${ }^{15}$ The term originates from the marijuana- (njaye-)smoking men of Kyaggwe who were active during the reign of Kabaka Mwanga II (Davis 2000: 41, note 12).
} 
navy jeans, a collar shirt and glasses - a formal appearance that contrasts with that of many of the people around him. Alex drops USh 2,500 into his hand. Without breaking his conversation, the man places the money into his pocket and marks a number under a column in his book. This man is George Mirembe, the proprietor of House of Faith, a savings and moneylending business in Nakasero. George makes his rounds of the market in the early evening, after vendors have generated money from their day's activities. He has around 500 customers who deposit relatively small amounts of money with him on a daily basis, which they then withdraw in full minus a service charge at the end of each month. ${ }^{16}$

George's family has been involved in the market for three generations. His mother followed his grandmother into the market, and she brought George during the school holidays. Her sudden death in 2004 marked the end of George's schooling and the start of his life in Nakasero. When describing his work, George talks in terms of 'service' rather than business: service to his family, to his people in the market, and to God. The name of his business, House of Faith, invokes this notion of service as well as that of trust, which is particularly important in his line of work. George's customers attribute their decision to save with him both to his long family history in Nakasero and to his 'fear of God', associations that provide a certain degree of insurance to their transactions. He reproduces these associations by preaching gospel sermons and sharing stories of his family.

Organizations such as House of Faith effectively socialize people's obligations to save money. Rather than a formal contractual agreement, the practice of saving is grounded in a personal relationship with someone who has an intimate knowledge of one's life and obligations. George encourages people to save money by visiting them in their place of work and talking about their plans for the future. His business enables people to earmark money for particular expenses, such as school fees, while protecting it from the claims of creditors, neighbours and spouses. Unplanned withdrawals - for example, withdrawals that do not take place at the end of the month - have to be personally negotiated with George. Critically, this service is mobile and flexible compared with that provided by high street banks, and does not require people to leave their goods unattended in the market.

After building up a base of customers, George decided to begin issuing loans through House of Faith:

I had a vision about collecting money together; I discovered that if Mr Boto is faithful, I can give him your money together with mine and solve his problem. Then the next day, he brings back your money, and the next time you are in trouble, I can give you Mr Boto's money. That is the system I introduced here. But you know the difficulty? Some people are not trustworthy ...

When deciding whether to make a loan, George consults people's individual savings histories, much like a high street bank. However, he draws upon an intricate knowledge of their biographies, their families, and their most pressing domestic expenses: for example, he rarely sanctions business loans close to the start of the

\footnotetext{
${ }^{16}$ This amounts to a charge of between 2 per cent and 3 per cent of the total amount saved.
} 
school term. This knowledge also extends to a concern with people's hearts. He explains that while men have 'a strong heart; a heart that doesn't fear to sin', women tend to have a heart that is more 'human' and 'kind'. As such, when a man tells you he will bring money back in a month, 'you know it will be two months at least', whereas most women will complete payment within a month. This understanding, which reflects broader stereotypes of profligate men and frugal women, has led George to pursue a policy of lending to men through their wives in cases where they both work in the market.

By issuing loans, House of Faith connects the fortunes of people across the market, drawing on the profits of a person in one area to provide for the rent or school fees of someone in another:

I see them, I save their money ... Some are bayaye, they steal people's money, [but] I always give them ideas, I always try to show them that you can work and earn something ... I'm happy that I've transformed some people's lives; I lend them other people's money so they can do what they want. Some even had no rooms ... I helped them and now they rent their own houses, they save that little money, and at the end of the month they pay the landlord, so for some their lives have changed.

George's testimony emphasizes his role in the transformation of people's lives in the market by moving money into places where it is seen to have more social efficacy, converting resources into uses previously constrained (Simone 2004b). This role enables George to acquire large numbers of savers (or followers), which benefits his business. It is a more visible role than that of the silent patron, arguably represented by Frank and Margaret. However, it is one that comes with relatively high levels of social and economic risk.

Before they are eligible to receive a loan, newcomers in Nakasero are required to develop a savings profile and identify two guarantors with profiles of their own. However, these loans are issued on the back of the savings of other members of the market. Consequently, George is required to manage his relationships with high earners very carefully in order to anticipate large withdrawals in advance. However, the socio-economic hierarchies of the market make it difficult for George to reject the requests of elder vendors in the shops or stalls, of which a number are members of his extended family. As a result, he has developed an array of indirect, non-verbal modes of refusal. For example, he evades areas in which an influential person has requested an unserviceable loan, and avoids the market altogether (sending his brother in his place) when there is no money left at the start of the school term.

George's interactions are illustrative of the purchase of Ganda frameworks of social relations in Nakasero, in which even successful businessmen must appease the requests of their elder neighbours. While senior members of the market may refuse the requests of others by invoking the moral categories of the muyaye (thug) and omulogo (witch), younger members of the market are required to be subtle and deferential when evading the requests of their elders. Nevertheless, George has lost significant amounts of money by extending loans to influential members of the market, including the coach of the market football team, and has been forced to leave on several occasions in order to raise enough capital to repay his other customers. 
George's relationship with Alex could be described as complex. Alex first encountered House of Faith in 2012, after asking others in the market where they saved their money. Impressed by Alex's ability to make daily savings, George introduced him to his church in Katwe and found him a place to live. He advised Alex to stop drinking alcohol and to save money for gumboots and gloves to improve the conditions of his work. However, the sharing of alcohol is an important social ritual in the Ghetto. Alex struggled to keep up with the rent payments on the house George had found him and began sleeping in the market again in 2013. The two men have stopped meeting socially, but Alex still saves his money with George. Although visibly disappointed by Alex's decision to keep drinking and sleeping in the market, George maintains that he still has 'the possibility to change'. Among the loans listed in the House of Faith book for June 2014 is one to Alex, recorded as '5,000 - mmere [food]'.

Darkness falls on the market as George collects the last of people's savings. It is 7 p.m. and the shops and stalls have closed, marking the end of Asian and European custom in the market. Frank is already on his hour-long drive home to Kitende in a car loaned to him by his mother. Margaret, meanwhile, takes a 20-minute boda-boda taxi ride back to Kigusu, arriving home in time to watch a South American soap opera. George is the next to leave, taking a 30-minute boda-boda home to his wife and two children in Katwe.

Still in the market, Stephen and his neighbours in the Kabengo and Parkyard light candles around the last of their produce. The edges of the market resemble a series of intricate shrines: pyramids of tomatoes, cucumbers and mangos illuminated by flickering candlelight. Stephen leaves after selling the last of his produce at around 9 p.m., taking an hour-long matatu taxi ride home to a room he shares with a cousin in Kawempe. He occasionally stays overnight in order to count produce trucks - and speculate on prices - in the early hours of the morning.

Now only Alex remains in the market, selling off the last of the produce he has salvaged over the course of the day while sharing a small bag of waragi (gin) with his neighbours. Other young men begin to gather on the corners of the market, anticipating the arrival of the early-morning trucks. Lying down in the entrance of Frank's shop, Alex is surrounded by dozens of other bodies - young, old, male, female - numbering around a hundred in total. He turns and attempts to get some rest before Frank's return in the early morning.

\section{Conclusions}

Alex Sserwanda's daily movements and interactions in Nakasero provide a window through which it is possible to observe the production and negotiation of social proximity in a diverse and competitive urban African setting. The organization of the market is often described with reference to notions of socio-spatial hierarchy: of 'high' and 'low' earners, 'first-' and 'third-class' produce, and 'open' and 'closed' areas of the market. Different areas of the market involve different rituals of entry, methods of sale and norms of social interaction. Interactions within and across these areas are situational in ways not captured by dualistic commercial roles, such as those of the vendor and customer, associate and competitor, employer and employee. Similarly, sociological frameworks of friendship or kinship are ill suited 
to a setting where the use of terms such as 'friend' and 'brother' is highly contingent. Instead, relationships develop around particular practices, such as the cleaning of a person's stall, the sharing of their space or the saving of their money, insofar as these practices are understood to entail obligations to others.

The organization of obligation in the market draws heavily on logics and idioms of Buganda cultural practice, including the moral imperative to show 'heart' through the acquisition of dependants. For example, Frank emphasizes the importance of providing support and advice to poorer members of the market, while Margaret and George describe their relationships with Alex through notions of support and survival. These obligations are negotiated through a range of moral categories, including those of the muyaye, the 'good boy', the 'husband snatcher' and the witch. Young men and women take great care to navigate these categories through skilful acts of movement, interaction and avoidance. Taken together, these logics and categories reproduce stark socio-economic inequalities in the market. However, they place these inequalities in the context of a functioning market society, connecting the work of different members of Nakasero and providing meaning to their interactions.

Alex's daily interactions in the market may be understood as an example of 'people as infrastructure', insofar as they are generative of 'social compositions across a range of singular capacities and needs' (Simone 2004b: 410). However, at the same time, these interactions are situated within a cultural space that places limits on what can be negotiated with whom. To put it another way, people's ability to improvise access to valued resources in the market is circumscribed by logics and categories that have long histories in Buganda, the cultural region in which Kampala is located. These findings have broader implications for the scholarship on social relations in African cities. In our pursuit of phenomena that 'burst out of conventional forms' of analysis (Guyer 2011: 475), we should not lose sight of the historical cultural idioms that continue to provide meaning to the activities and relations of urban African inhabitants.

\section{Acknowledgements}

This article was made possible by the friendship and generosity of the people of Nakasero market. The final manuscript has benefited from generous discussions with colleagues at the Nordic Africa Institute, the African Studies Association, and the Makerere Institute of Social Research. Special thanks to Laura Camfield, Ben Jones, Holly Hanson, Cecile Jackson, Dan Wroe, Jesper Bjarnesen, Mats Utas, Annika Teppo and two anonymous reviewers for their helpful comments on earlier versions. The research on which this article is based was funded by the School of International Development (DEV) at the University of East Anglia, and the British Institute in East Africa.

\section{References}

Bähre, E. (2007) 'Reluctant solidarity: death, urban poverty and neighbourly assistance in South Africa', Ethnography 8 (1): 33-59.

Baland, J.-M., C. Guirkinger and C. Mali (2011) 'Pretending to be poor: borrowing to escape forced solidarity in Cameroon', Economic Development and Cultural Change 60 (1): 1-16. 
Bohannan, P. and G. Dalton (1962) Markets in Africa. Evanston IL: Northwestern University Press.

Brennan, J. R. (2013) 'Rents and entitlements: reassessing Africa's urban pasts and futures', Afrika Focus 26 (1): 37-49.

Clark, G. (1994) Onions Are My Husband: survival and accumulation by West African market women. Chicago IL: University of Chicago Press.

Davis, P. J. (2000) 'On the sexuality of "town women" in Kampala', Africa Today 47 (3): 29-60.

De Boeck, F. and F. Plissart (2004) Kinshasa: tales of the invisible city. Tervuren and Ludion: Royal Museum of Central Africa and Vlaams Architectuureninstituut Vai.

Englund, H. (1995) 'Witchcraft, modernity and the person: the morality of accumulation in central Malawi', Critique of Anthropology 16 (3): 257-79.

Epstein, A. L. (1967) 'Urbanization and social change in Africa', Current Anthropology 8 (4): 275-95.

Frankland, S. (2007) 'No money, no life: surviving on the streets of Kampala' in J. Staples (ed.), Livelihoods at the Margins of the State. London: Left Coast Press.

Geschiere, P. (1997) The Modernity of Witchcraft: politics and the occult in postcolonial Africa. Charlottesville VA: University of Virginia Press.

Gluckman, M. (1956) Custom and Conflict in Africa. London: Blackwell Publishers.

Gluckman, M. (1971) 'Tribalism, ruralism and urbanism in South and Central Africa' in V. Turner (ed.), Colonialism in Africa 1870-1960. Vol. 3: Profiles of change: African society and colonial rule. Cambridge: Cambridge University Press.

Grimm, M., R. Hartwig and J. Lay (2013) 'Does forced solidarity hamper investment in small and micro enterprises?' IZA Discussion Paper 7229. Bonn: Institute for the Study of Labor (IZA).

Guyer, J. I. (1993) 'Wealth in people and self-realization in equatorial Africa', Man 28 (2): 243-65.

Guyer, J. I. (2011) 'Describing urban "no man's land” in Africa', Africa 81 (3): 474-92.

Hanson, H. E. (2003) Landed Obligation: the practice of power in Buganda. Portsmouth NH: Heinemann.

Jones, J. L. (2010) "Nothing is straight in Zimbabwe": the rise of the kukiya-kiya economy 2000-2008', Journal of Southern African Studies 36 (2): 285-99.

Kapchan, D. (1996) Gender on the Market: Moroccan women and the revoicing of tradition. Philadelphia PA: University of Pennsylvania Press.

Mayer, P. (1971) Townsmen or Tribesmen: conservatism and the process of urbanization in a South African city. Oxford: Oxford University Press.

Mbembe, A. and J. Roitman (1995) 'Figures of the subject in times of crisis', Public Culture 7 (2): 323-52.

Monteith, W. (2017a) 'Showing "heart" through ethnography: ethical entanglements in a Ugandan marketplace', CITY 21 (2): 178-89.

Monteith, W. (2017b) 'Markets and monarchs: indigenous urbanism in postcolonial Kampala', Settler Colonial Studies, pp. 1-19 [online].

Musisi, N. (1995) 'Buganda women's night market activities' in F. K. Ekechi and B. House-Midamba (eds), African Market Women and Economic Power. Westport CT: Greenwood Press. 
Naliwaiko, A. (1990) 'The bag boys: Nakasero market boys'. MISR Occasional Paper 8. Kampala: Makerere Institute of Social Research.

Nuttall, S. and A. Mbembe (2008) Johannesburg: the elusive metropolis. Johannesburg and Durham NC: Witwatersrand University Press and Duke University Press.

Owusu-Sekyere, E. (2014) 'Scavenging for wealth or death? Exploring the health risk associated with waste scavenging in Kumasi, Ghana', Ghana Journal of Geography 6: 63-80.

Pietilä, T. (2007) Gossip, Markets, and Gender: how dialogue constructs moral value in post-socialist Kilimanjaro. Madison WI: University of Wisconsin Press.

Scherz, C. (2014) Having People, Having Heart: charity, sustainable development and problems of dependence in central Uganda. Chicago IL: University of Chicago Press.

Simone, A. (2004a) For the City yet to Come: changing African life in four cities. Durham NC: Duke University Press.

Simone, A. (2004b) 'People as infrastructure: intersecting fragments in Johannesburg', Public Culture 16 (3): 407-29.

Singer, S., E. Amorós and D. Moska (2015) Global Entrepreneurship Monitor: 2014 global report. London: Global Entrepreneurship Research Association (GERA).

Southall, A. and P. Gutkind (1957) 'Townsmen in the making: Kampala and its suburbs'. East African Studies 9. Kampala: East African Institute of Social Research.

Teppo, A. (2015) 'Moral communities in African cities', Anthropology Southern Africa 38 (3-4): 284-9.

UN-Habitat (2010) Solid Waste Management in the World's Cities. London and Washington DC: Earthscan for United Nations Human Settlements Programme (UN-Habitat).

Weiss, B. (2002) 'Thug realism: inhabiting fantasy in urban Tanzania', Cultural Anthropology 17 (1): 93-124.

Wirth, L. (1938) 'Urbanism as a way of life', American Journal of Sociology 44 (1): $1-24$.

\begin{abstract}
African marketplaces have long been understood as ambivalent spaces; as sites of compliance and transgression, domination and resistance. This ambivalence comes into sharp focus in the urban marketplaces that have absorbed a large proportion of the African workforce over the past four decades. One the one hand, urban markets offer opportunities for the forging of new relationships, or 'fictive kin', beyond the confines of consanguinity and affinity. However, on the other hand, they are fiercely competitive places in which strangers skilfully intrude into one's life. Succeeding in the market therefore requires the striking of a skilful balance between accumulation and redistribution, disclosure and concealment. This article presents an analysis of the everyday interactions and exchanges facilitated by the movements of a waste picker in Nakasero market, the oldest marketplace in Kampala, Uganda. Amid the current emphasis on improvization and provisionality as key features of urban African life, it demonstrates the importance of long-standing cultural idioms, such as omutima ('heart'),
\end{abstract}


in providing structure and meaning to the interactions of urban African inhabitants.

\section{Résumé}

On présente depuis longtemps les marchés africains comme des espaces ambivalents ; des lieux de conformité et de transgression, de domination et de résistance. Cette ambivalence apparaît nettement sur les marchés urbains qui ont absorbé une large proportion de la main-d'œuvre africaine ces quarante dernières années. D'un côté, les marchés urbains offrent des opportunités pour forger de nouvelles relations, ou liens de "parenté fictive », qui dépassent le cadre de la consanguinité et de l'affinité. Mais d'un autre côté, ce sont des lieux farouchement concurrentiels dans lesquels des étrangers s'immiscent habilement dans la vie d'autrui. Réussir au sein du marché exige donc de trouver un habile équilibre entre accumulation et redistribution, divulgation et dissimulation. Cet article présente une analyse des interactions et échanges courants facilités par les déplacements d'un ramasseur de déchets sur le marché de Nakasero, le plus vieux marché de Kampala (Ouganda). Alors que l'accent est mis actuellement sur l'improvisation et la provisionnalité en tant que principales caractéristiques de la vie urbaine africaine, l'article démontre l'importance des vieux idiomes culturels, comme omutima (« cœur »), lorsqu'il s'agit de fournir une structure et du sens aux interactions des habitants urbains africains. 